\title{
Simulation model for thrombin generation in plasma
}

Citation for published version (APA):

Willems, G. M., Lindhout, T., Hermens, W. T., \& Hemker, H. C. (1991). Simulation model for thrombin generation in plasma. Haemostasis, 21(4), 197-207. https://doi.org/10.1159/000216229

Document status and date:

Published: 01/01/1991

DOI:

10.1159/000216229

Document Version:

Other version

\section{Please check the document version of this publication:}

- A submitted manuscript is the version of the article upon submission and before peer-review. There can be important differences between the submitted version and the official published version of record.

People interested in the research are advised to contact the author for the final version of the publication, or visit the DOI to the publisher's website.

- The final author version and the galley proof are versions of the publication after peer review.

- The final published version features the final layout of the paper including the volume, issue and page numbers.

Link to publication

\footnotetext{
General rights rights.

- You may freely distribute the URL identifying the publication in the public portal. please follow below link for the End User Agreement:

www.umlib.nl/taverne-license

Take down policy

If you believe that this document breaches copyright please contact us at:

repository@maastrichtuniversity.nl

providing details and we will investigate your claim.
}

Copyright and moral rights for the publications made accessible in the public portal are retained by the authors and/or other copyright owners and it is a condition of accessing publications that users recognise and abide by the legal requirements associated with these

- Users may download and print one copy of any publication from the public portal for the purpose of private study or research.

- You may not further distribute the material or use it for any profit-making activity or commercial gain

If the publication is distributed under the terms of Article $25 \mathrm{fa}$ of the Dutch Copyright Act, indicated by the "Taverne" license above, 
Haemostasis

Managing Editor: H.C. Hemker, Maastricht

\title{
Simulation Model for Thrombin Generation in Plasma
}

\author{
George M. Willems ${ }^{\mathrm{a}}$, Theo Lindhout ${ }^{\mathrm{b}}$, Wim Th. Hermens ${ }^{\mathrm{a}}$, H. Coenraad Hemker ${ }^{\mathrm{b}}$ \\ ${ }^{a}$ Cardiovascular Research Institute Maastricht and \\ ${ }^{b}$ Department of Biochemistry, University of Limburg, Maastricht, The Netherlands
}

Key Words. Prothrombin activation - Computer simulation model - Regulation model Factor $\mathrm{V}$ activation - Hirudin - Activation threshold - Down-regulation by inhibitors

\begin{abstract}
A simulation model for the production of thrombin in plasma is presented. Values of the reaction rate constants as determined in purified systems are used and the model is tested by comparison of simulations of factor $\mathrm{Xa}$, factor $\mathrm{Va}$ and thrombin generation curves with experimental data obtained in thromboplastin-activated plasma. Simulations of the effect of hirudin indicate that factor $\mathrm{V}$ is predominantly activated by thrombin and not by factor Xa. The model predicts a threshold value for the factor Xa production which, if exceeded, results in explosive and complete activation of prothrombinase. The dependence of this threshold value on different negative feedback reactions, e.g. the inactivation of thrombin and factor $\mathrm{Xa}$ by antithrombin III (+ heparin), is investigated. The threshold value, for control plasma in the range of 1-10 $\mathrm{p} M$ total factor Xa production, can be raised two orders of magnitude by accelerated inactivation of factor $\mathrm{Xa}$ and prothrombinase but is hardly affected by a tenfold increase in the rate of thrombin inactivation or by increased production of activated protein $\mathrm{C}$. This latter effect, however, results in a more gradual input-response relation between factor $\mathrm{Xa}$ input and the extent of prothrombinase activation.
\end{abstract}

\section{Introduction}

The dual requirements of rapid clot formation in response to vascular lesions and prevention of spontaneous formation or expansion of clots suggest an intricate, highly nonlinear, regulation of thrombin production. Extensive research during past decades has produced detailed knowledge at the molecular level of the reaction mechanisms involved in the successive activation of the clotting (co)factors [1]. Thus emerged the concept that the explosive amplification of procoagulant activity is due to the cascade of successive activations of the serine proteases with positive feedback through activation of 
cofactors. Assembly with its cofactor, in enzyme-cofactor complexes adsorbed to the procoagulant lipid surface, greatly enhances the conversion capacity of the enzyme. The response is limited by localization of the amplified response to the lipid surface at the site of injury. This localized response is regulated downward by rather effective scavenging of the proteases by antithrombin III (ATIII), and $\alpha_{2}$-macroglobulin inactivation of the cofactors Va and VIIIa by activated protein $\mathrm{C}$, and inhibition of tissue factor by extrinsic pathway inhibitor (EPI). Studies of clotting factor activation in plasma support the above-mentioned picture and especially stress the pivotal role of the feedback activation of, e.g., factor $V$ for the amplification of the response [2-6]. However, apparent discrepancies between data from purified systems and observations in plasma have also arisen. In purified systems, for instance, it was shown that factor $\mathrm{Xa}$ activates factor $\mathrm{V}$ as effectively as thrombin [7], while it was concluded from experiments in plasma that thrombin is the only effective activator of factor $V$ [5].

Due to the multiple and interacting protein conversions, the interpretation of data on thrombin generation in plasma requires a dynamic model. Therefore a model for the generation of prothrombinase activity in plasma was constructed, using reaction rates derived from experiments in purified systems. The response on a transient input of factor $\mathrm{Xa}$ into plasma is considered as a function of thrombin generation by factor $\mathrm{Xa}$ and prothrombinase, feedback activation of factor $\mathrm{V}$ by thrombin, assembly of prothrombinase, elimination of factor $\mathrm{Xa}$ and thrombin by ATIII, and inactivation of factor $\mathrm{Va}$ by thrombin-activated protein $\mathrm{C}$ (APC). In these respects, it deviates from earlier models that either did not account for feedback activation of factor $V$ by prothrombin [8-10] or assumed constant inactivation of factor $\mathrm{Va}$ [11].

\section{Methods}

\section{The model}

The various mechanisms included in the simulation model are summarized in the following scheme (see also table 1):

\begin{tabular}{|c|c|c|c|}
\hline \multicolumn{2}{|c|}{ Activation } & \multicolumn{2}{|c|}{ Inactivation } \\
\hline (1a) & $\mathrm{F}(\mathrm{t}) \rightarrow \mathrm{Xa}$ & (1b) & $\begin{array}{l}\mathrm{Xa}+\mathrm{ATIII} \rightarrow \\
\mathrm{Xa}-\mathrm{ATIII}\end{array}$ \\
\hline $\begin{array}{l}(2 a) \\
(2 b)\end{array}$ & $\begin{array}{l}\mathrm{V} \stackrel{\mathrm{Ha}}{\longrightarrow} \mathrm{Va} \\
\mathrm{V} \stackrel{\mathrm{Xa}}{\longrightarrow} \mathrm{Va}\end{array}$ & (2c) & $\begin{array}{l}\text { Va } \stackrel{A P C}{\longrightarrow} \\
\text { Va-inactive }\end{array}$ \\
\hline (3a) & $\begin{array}{l}\mathrm{Va}+\mathrm{Xa} \longleftrightarrow \\
\mathrm{Va}-\mathrm{Xa}\end{array}$ & (3b) & $\begin{array}{l}\text { Va-Xa }+ \text { ATIII } \rightarrow \\
\text { Va }+ \text { Xa-ATIII } \\
\text { Va-Xa } \stackrel{\text { APC }}{\longrightarrow} \\
\text { Va-inactive }+ \text { Xa }\end{array}$ \\
\hline $\begin{array}{l}(4 a) \\
(4 b)\end{array}$ & $\begin{array}{l}\text { II } \stackrel{\mathrm{Xa}}{\longrightarrow} \text { IIa } \\
\mathrm{II} \stackrel{\mathrm{Va}-\mathrm{Xa}}{\longrightarrow} \text { IIa }\end{array}$ & $(4 c)$ & $\begin{array}{l}\text { IIa }+ \text { ATIII } \rightarrow \\
\text { IIa-ATIII }\end{array}$ \\
\hline (5a) & $\mathrm{C} \stackrel{\mathrm{IIa}}{\rightarrow} \mathrm{APC}$ & (5b) & $\begin{array}{l}\text { APC } \rightarrow \\
\text { APC-inactive }\end{array}$ \\
\hline
\end{tabular}

(6) Fibrinogen $\stackrel{\text { IIa }}{\longrightarrow}$ Fibrin

Generation and Inactivation of Factor Xa. The factor $\mathrm{Xa}$ generation, induced by thromboplastin, is considered to be a given input $F(t)$ simulated by:

$$
F(t)=Q_{x a} \alpha \cdot \exp (-\alpha t),
$$

where $\mathrm{Q}_{\mathrm{Xa}}$ is the total amount factor $\mathrm{Xa}$ produced and $\alpha$ the mono-exponential decay rate associated with the disappearance of the tissue factor VIIa activity. The inactivation of factor Xa by ATIII is modelled by a first-order reaction with rate constant $k_{i}$. The rate enhancement of this reaction by heparin is reflected in higher values of this parameter [13]. The 
Table 1. Reactions rates of the simulation model

\begin{tabular}{llll}
\hline Reaction & Kinetic parameters & References \\
\hline (1a) & & $\mathrm{Q}_{\mathrm{X}_{\mathrm{a}}}=20 \mathrm{n} M ; \alpha=1 \mathrm{~min}^{-1}$ & estimated, see text \\
(1b) & $\mathrm{M}^{\mathrm{a}}$ & $\mathrm{k}_{\mathrm{i}}=0.25 \mathrm{~min}^{-1}$ & 7 \\
\hline (2a) & $\mathrm{M}$ & $\mathrm{k}_{\mathrm{cat}}=14 \mathrm{~min}^{-1} ; \mathrm{K}_{\mathrm{m}}=72 \mathrm{n} M$ & 7 \\
\hline (2b) & $\mathrm{M}$ & $\mathrm{k}_{\mathrm{cat}}=2.6 \mathrm{~min}^{-1} ; \mathrm{K}_{\mathrm{m}}=10 \mathrm{n} M$ & 16 \\
\hline (2c) & $\mathrm{M}$ & $\mathrm{k}_{\mathrm{cat}}=24 \mathrm{~min}^{-1} ; \mathrm{K}_{\mathrm{m}}=20 \mathrm{n} M$ & 15 \\
\hline (3a) & $\mathrm{S}$ & $\mathrm{k}_{\mathrm{p}}=10 \mathrm{n} M^{-1} \mathrm{~min}^{-1} ;$ & 17 \\
(3b) & $\mathrm{F}$ & $\mathrm{k}_{\mathrm{i}}=0.05 \mathrm{~min}^{-1} ;$ & 16 \\
\hline (3c) & $\mathrm{M}$ & $\mathrm{k}_{\mathrm{cat}}=24 \mathrm{~min}^{-1} ; \mathrm{K}_{\mathrm{m}}=20 \mathrm{n} M$ & 18 \\
\hline (4a) & $\mathrm{M}$ & $\mathrm{k}_{\mathrm{cat}}=2.3 \mathrm{~min}^{-1} ; \mathrm{K}_{\mathrm{m}}=58 \mathrm{n} M$ & 15 \\
(4b) & $\mathrm{M}$ & $\mathrm{k}_{\mathrm{cat}}=2,000 \mathrm{~min}^{-1} ; \mathrm{K}_{\mathrm{m}}=210 \mathrm{n} M$ & 18 \\
(4c) & $\mathrm{F}$ & $\mathrm{k}_{\mathrm{i}}=1.3 \mathrm{~min}^{-1}$ & 15 \\
\hline (5a) & $\mathrm{F}$ & $\mathrm{k}=0.0014 \mathrm{~min}^{-1}$ & 12 \\
\hline (5b) & $\mathrm{F}$ & $\mathrm{k}_{\mathrm{i}}=0.35 \mathrm{~min}^{-1}$ & estimated, see text \\
\hline (6) & $\mathrm{M}$ & $\mathrm{K}_{\mathrm{m}}=2 \mu M$ (corrected for multiple cleavage sites) & estimated, see text \\
\hline
\end{tabular}

a Kinetics:

$\mathbf{M}=$ Michaelis-Menten mechanism: $\mathrm{V}=\mathbf{k}_{\mathrm{cat}} \cdot \mathrm{E} \cdot \mathrm{S} /\left(\mathrm{S}+\mathrm{K}_{\mathrm{m}}\right)$

$\mathrm{F}=$ First-order reaction: $\mathrm{V}=\mathrm{k} \cdot \mathrm{E}$

$\mathrm{S}=$ Second-order reaction: $\mathrm{V}=\mathrm{k} \cdot \mathrm{Va} \cdot \mathrm{Xa}$

It was assumed in the simulations that no activated clotting factors were present before addition of the thromboplastin trigger, i.e. the initial values $(t=0)$ for the activated factors were set to zero. Initial values for the unactivated proteins were: prothrombin: $1 \mu M$; factor $\mathrm{V}: 30 \mathrm{n} M$; protein $\mathrm{C}$ : $100 \mathrm{n} M$; fibrinogen: $10 \mu M$.

values of $\mathrm{Qx}_{\mathrm{a}}$ and $\alpha$ are obtained by fitting $\mathrm{F}(\mathrm{t})$ to the observed time-activity curve of factor $\mathrm{Xa}$.

Generation and Inactivation of Factor Va. Activation of factor $\mathrm{V}$ by factor $\mathrm{Xa}$ and thrombin are both included in the model $[7,14]$. In these reactions, we must account for competition between prothrombin and factor $\mathrm{V}$ for factor $\mathrm{Xa}$. For two substrates with concentrations $S_{1}$ and $S_{2}$, competing for the same enzyme with concentration $E$, the conversion rate of $S_{\mathrm{I}}$ is given by:

$$
\mathrm{k}_{\text {call }} \cdot \mathbf{E} \cdot \mathrm{S}_{1} /\left[\mathrm{S}_{1}+\mathrm{K}_{\mathrm{ml}}\left(1+\mathrm{S}_{2} / \mathrm{K}_{\mathrm{m} 2}\right)\right] \text {, }
$$

where $k_{\text {call }}$ is the maximal turnover rate of $S_{1}$ by the enzyme and $\mathrm{K}_{\mathrm{m} 1}, \mathrm{~K}_{\mathrm{m} 2}$ are the Michaelis constants of the conversion of $S_{1}$ resp. $S_{2}$ by $E$. Activated factor $V$ is degraded by activated protein C (APC).
Generation and Inactivation of Prothrombinase. Because initially the factor $\mathrm{Xa}$ and factor $\mathrm{Va}$ concentrations can both be very low $(<0.01 \mathrm{n} M)$ and the second-order association rate constant on small unilamellar vesicles is estimated to be $\mathrm{k}_{\mathrm{p}}=10 \mathrm{n} M^{-1} \mathrm{~min}^{-1}$ [15] the assembly rate easily becomes rate limiting. Therefore, instantaneous equilibrium (quasi steady state) cannot be assumed and the transient kinetics must be included in the model. The inactivation rate of prothrombinase as a result of factor $\mathrm{Va}$ inactivation by APC is assumed to be identical to the inactivation rate of uncomplexed factor $\mathrm{Va}$. This may represent an overestimation because some protection of factor Va by factor Xa has been reported [16]. The factor Xa complexed in the prothrombinase can be inactivated by ATIII (+ heparin) although at a about 
$80 \%$ lower rate than lipid-bound or free factor $\mathrm{Xa}$ [17].

Generation and Inactivation of Thrombin. The catalytic efficiency of both factor $\mathrm{Xa}$ and the factor $\mathrm{Xa}$-Va complex increases enormously when bound to phospholipid [18]. Therefore it is assumed that the conversion rate is determined by the lipid-bound factor $\mathrm{Xa}$ and $\mathrm{Va}-\mathrm{Xa}$ and the contribution of free factor $\mathrm{Xa}$ and $\mathrm{Va}-\mathrm{Xa}$ is neglected. The association to the lipid generally is rapid [19] and an instantaneous equilibrium is assumed. The number of bindings sites then becomes an important determinant of the maximal prothrombinase activity.

Generation and Inactivation of Activated Protein $C$. Both activation of protein $\mathrm{C}$ by thrombin and inactivation of APC are described by apparent first-order reactions and the rate constants are adjusted by fitting the factor $\mathrm{Va}$ disappearance curve.

Conversion of Fibrinogen by Thrombin. This reaction is included to account for the reduction of the activation rate of factor $V$ by thrombin, caused by the competition of fibrinogen with factor $\mathrm{V}$ for thrombin.

The enzymatic conversions and the inactivation of thrombin and factor Xa by ATIII require at least two steps, a bimolecular reaction resulting in complex formation followed by a rate-limiting final step, such as proteolytic cleavage of the substrate. In order to avoid unwarranted complexity, these reactions, with the exception of the assembly of prothrombinase, are approximated $\mathrm{Ly}$ using the quasi-steady-state approximation. This is justified at a time scale of minutes, as the concentration of the abundant reactant (the substrate or ATIII) in these reactions exceeds $30 \mathrm{nM}$ so that, even for values as low as $5 \times 10^{-3} \mathrm{n}^{-1} \mathrm{~s}^{-1}$ for the second-order rate constant of the association reaction, the half-time for equilibration is less than $0.06 \mathrm{~min}$. Thus the enzymatic reactions are described by the classical Michaelis-Menten model, and the inactivation reactions are considered as apparent first-order reactions.

Numerical Integration. As the set of differential equations is moderately to very stiff (with hirudin), a stiffly stable integration routine, the variable-order variable-step implementation of the backward integration formula supplied as routine D02EAF in the NAG library [20] was employed for numerical calculation of the solution. The accuracy, target $10^{-4} \mathrm{n} M$, of the simulations was checked for several representative cases by comparison of the results for several values of the error control parameter.

\section{Results and Discussion}

\section{Generation of Thrombin and Factor $\mathrm{Va}$} in Thromboplastin-Activated Plasma

Figure 1 shows the response of the complete simulation model on a trigger of transient factor Xa production. Using the model parameters presented in table 1 , the total amount of factor $\mathrm{Xa}$ production $\left(\mathrm{Q}_{\mathrm{Xa}}\right)$ and the decay rate $(\alpha)$ of the factor Xa production were estimated from the factor Xa time-activity curve. Then the activation and inactivation rate constants of protein $\mathrm{C}$ were adjusted in order to obtain agreement between model prediction and observed factor $\mathrm{Va}$ activities. The activation pathway of factor $\mathrm{V}$ by factor $\mathrm{Xa}$ proved totally irrelevant in this simulation, values of $k_{\text {cat }}$ between 0 and $3 \mathrm{~min}^{-1}$ did not change the result. Fitting of the thrombin generation curve revealed that the quantity of available lipid binding sites for prothrombinase had to be limited to $1 \mathrm{n} M$ (about $0.5 \mu M$ lipid), otherwise thrombin peaked too early. There are no data in the literature on this parameter but lipid limitation has been demonstrated in thromboplastin-activated plasma [21]. The observed trombin curve was measured by an amidolytic assay (S2238) in which thrombin inactivated by $\alpha_{2}$-macroglobulin has about $50 \%$ of the activity of thrombin and this causes the plateau level of thrombin activity in the experimental curve. The lower peak value of the measured thrombin activity compared to the simulation is probably related to clot formation after about $1 \mathrm{~min}$ and binding of part of the thrombin to this clot. Beyond these differences, that affect only the measurement of thrombin activity and not the parameter fit based on the factor $\mathrm{Va}$ and factor Xa plasma activities, a good agreement between model and experimental data is apparent. 


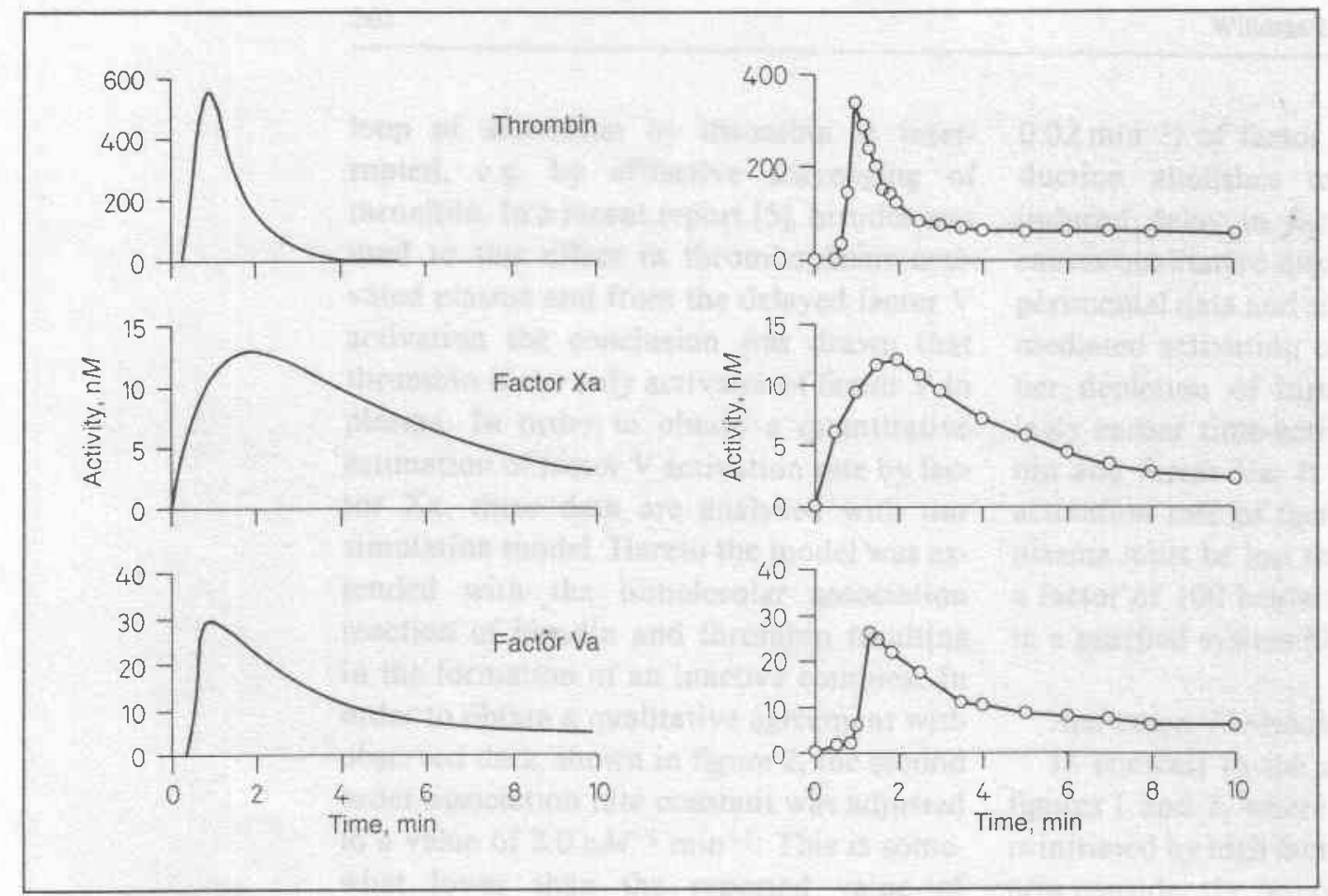

Fig. 1. Model simulations (left panel) and measured plasma activities (right panel) of thrombin, factor Xa and factor Va. Plasma, activated with 1/30 (vol/vol) thromboplastin. Experimental data from Pieters [4].

\section{Time Delay of Prothrombin Activation}

The time lag of thrombin generation was found qualitatively to be largely determined by the product of three reaction rates involved in the feedback activation loop of factor $\mathrm{V}$ by thrombin, that is the product $\mathrm{k}_{\mathrm{p}} \times$ $k_{\text {cat }}(2 a) \times k_{\text {cat }}(4 b)$ (table 1). Reduction of each of these reaction rates results in similar extensions of the time lag. Reduction of prothrombinase activity appears to cause the largest delay for a given proportional reduction of the reaction rates. The model behavior is relatively insensitive to small changes in these parameters. The time lag of $1 \mathrm{~min}$, as observed in plasma, (fig. 1), required a reduction of one of these reaction rates by nearly one order of magnitude, compared to the values in table 1 . However, limitation of the number of lipid binding sites for prothrombinase to the plausible value of $1 \mathrm{n} M$ offers a much simpler explanation. Although this issue requires further experiments, at the moment the lipid limitation appears the best explanation, and is incorporated in the model on the sequel of this paper.

\section{Inhibition of Thrombin by Hirudin:}

Factor V in Plasma Is Not Activated by

Factor $X a$

The simulations in figure 1 showed that the contribution of factor $\mathrm{V}$ activation by factor $\mathrm{Xa}$ is unimportant unless the feedback 
loop of activation by thrombin is interrupted, e.g. by efffective scavenging of thrombin. In a recent report [5], hirudin was used to this effect in thromboplastin-activated plasma and from the delayed factor $\mathrm{V}$ activation the conclusion was drawn that thrombin is the only activator of factor $\mathrm{V}$ in plasma. In order to obtain a quantitative estimation of factor $\mathrm{V}$ activation rate by factor $\mathrm{Xa}$, these data are analyzed with our simulation model. Hereto the model was extended with the bimolecular association reaction of hifudin and thrombin resulting in the formation of an inactive complex. In order to obtain a qualitative agreement with observed data, shown in figure 2, the second order association rate constant was adjusted to a value of $2.0 \mathrm{nM}^{-1} \mathrm{~min}^{-1}$. This is somewhat lower than the reported value of $5.3 \mathrm{nM}^{-1} \mathrm{~min}^{-1}$ [22], but this is consistent with the sensitivity of this reaction to the ionic strength also shown in that report. Figure 2 shows an excellent qualitative agreement between model simulations when it is assumed that only thrombin contributes to factor $\mathrm{V}$ activation (left panel) and observed (right panel) plasma activity curves. It appears that despite the virtually immediate elimination of thrombin by hirudin, the remaining small amounts of thrombin activate sufficient factor $\mathrm{V}$ for the generation of considerable prothrombinase activity. After $5 \mathrm{~min}$, nearly $500 \mathrm{nM}$ thrombin is formed in the presence of $500 \mathrm{nM}$ hirudin, whereas the factor Xa uncomplexed with factor Va could only produce $100 \mathrm{nM}$ of thrombin in this time. This thrombin production results ultimately in nearly complete depletion of hirutin, followed by a rapid rise of plasma thrombin and complete activation of factor $V$. The simulations in figure 3 show that even a minute catalytic activity $\left(\mathrm{k}_{\mathrm{cat}}=\right.$
$0.02 \mathrm{~min}^{-1}$ ) of factor $\mathrm{Xa}$ in factor $\mathrm{Va}$ production abolishes most of the hirudininduced delay in factor $\mathrm{V}$ activation and causes qualitative discrepancies between experimental data and simulations. Factor-Xamediated activation of factor $\mathrm{V}$ causes earlier depletion of hirudin and correspondingly earlier time-activity curves of thrombin and factor Va. It is concluded that the activation rate of factor $\mathrm{V}$ by factor $\mathrm{Xa}$ in plasma must be less than $0.02 \mathrm{~min}^{-1}$, that is a factor of 100 below the value determined in a purified system [7].

\section{Activation Threshold}

In contrast to the situation presented in figures 1 and 2, where thrombin generation is initiated by high factor Xa generations, we now consider the response to very low factor $\mathrm{Xa}$ generations. For small total factor $\mathrm{Xa}$ generations of finite duration, the activation delay may become so long that the factor Xa concentration has dropped to negligible levels before the appearance of factor Va. Then the assembly rate of prothrombinase, proportional to the product of the factor $\mathrm{Va}$ and $\mathrm{Xa}$ concentrations becomes rate limiting, the feedback loop is interrupted and only very limited activation occurs. This effect was studied quantitatively by using the simulation model to predict the system response upon a factor $\mathrm{Xa}$ input, $\mathrm{F}(\mathrm{t})=\mathrm{Q}_{\mathrm{Xa}} \cdot \alpha$. $\exp (-\alpha \mathrm{t})$ with $\alpha=1.0 \mathrm{~min}^{-1}$, as a function of the total factor $\mathrm{Xa}$ production $\left(\mathrm{Q}_{\mathrm{Xa}}\right)$. Lipid binding sites for factor $\mathrm{Xa}$ and prothrombinase were kept constant at $1 \mathrm{n} M$. The simulations thus purely reflect the effect of variable production capacity of factor $\mathrm{Xa}$, for instance due to different amounts of tissue factor. Figure 4 indeed shows that for total factor $\mathrm{Xa}$ inputs below threshold values of about 0.5 and $2 \mathrm{pM}$, the activation of 


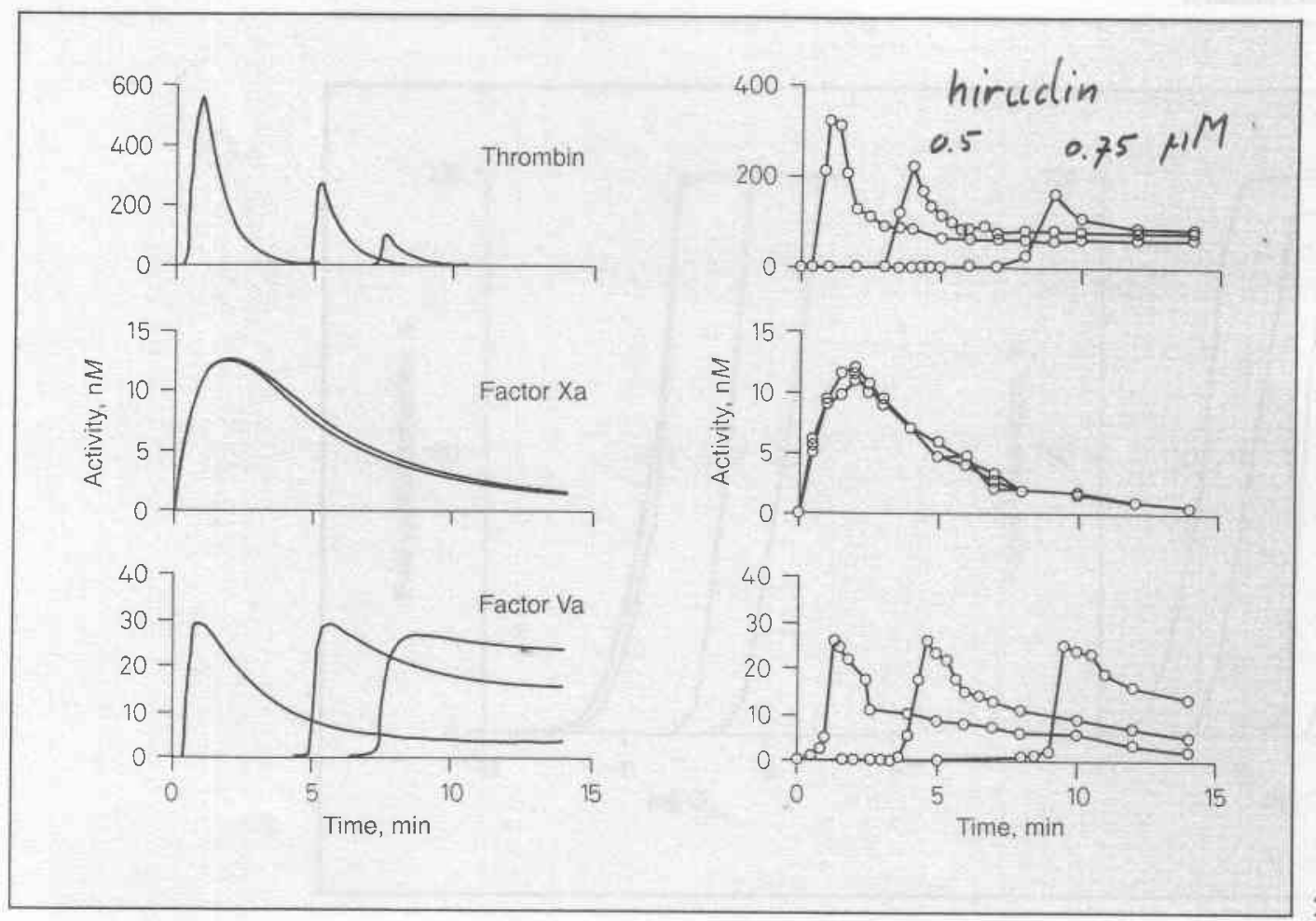

Fig. 2. Effect of addition of hirudin on the activation of thromboplastin-triggered plasma. Left panel shows model simulations, assuming no activation of factor $\mathrm{V}$ by factor $\mathrm{Xa}$, and the right panel the observed plasma activities of thrombin, factor $\mathrm{Xa}$ and factor Va. Hirudin concentrations were 0,500 and $750 \mathrm{nM}$. Experimental data are from Pieters [5].

Fig. 3. The effect of the rate of factor $\mathrm{V}$ activation by factor Xa. Indicated are simulations of plasma activity curves for a hirudin concentration of $750 \mathrm{nM}$ and for values of $k_{\text {cat }}$ of factor $\mathrm{V}$ activation by factor $\mathrm{Xa}$ equal to $0.0,0.02,0.1,0.5$, and $2.6 \mathrm{~min}^{-1}$.
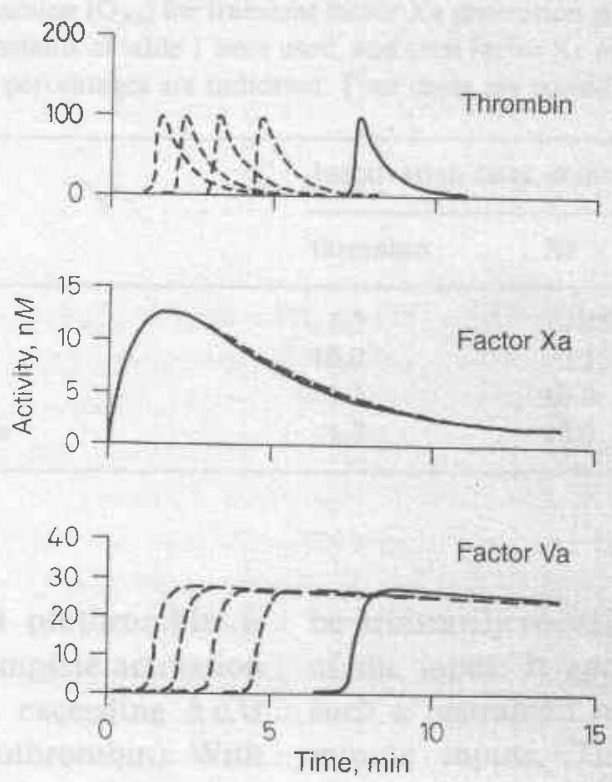


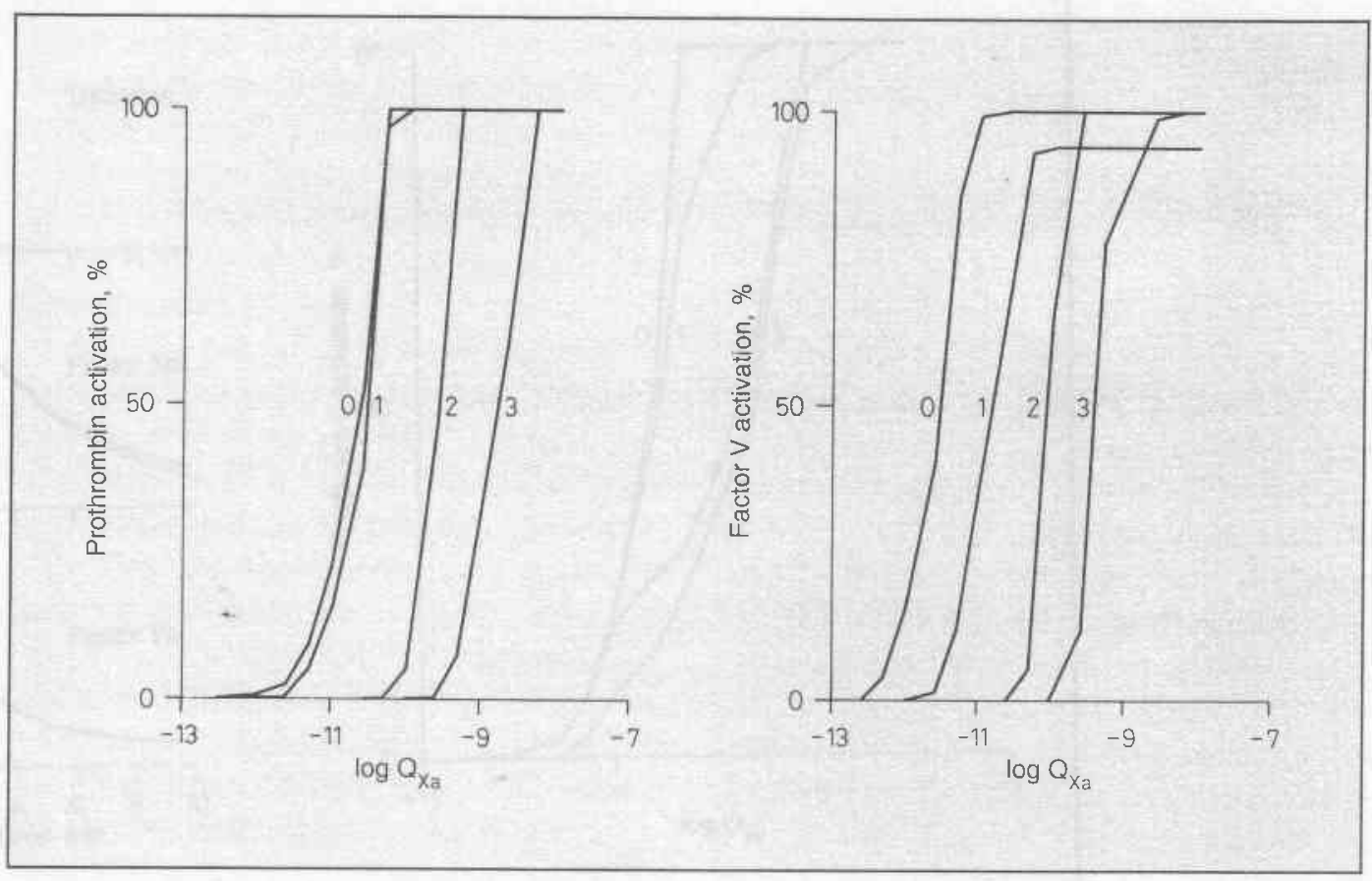

Fig. 4. Response on low factor $\mathrm{Xa}$ generations. The extent of activation of factor $\mathrm{V}$ and prothrombin as a function of total factor $X a$ production $\left(Q_{X_{a}}\right)$ for transient factor $X_{a}$ generation given by $F(t)=Q_{X_{a}} \alpha \cdot \exp (-\alpha t)$ with $\alpha=1$. The reaction rate constants of table 1 were used, and total factor $\mathrm{X}$ a production, $\mathrm{QX}_{\mathrm{X}}$, was varied as indicated. Ultimately activated percentages are indicated. Four cases are considered:

\begin{tabular}{|c|c|c|c|c|}
\hline & \multicolumn{3}{|c|}{ Inactivation rates, $\min ^{-1}$} \\
\hline & & thrombin & $\mathrm{Xa}$ & prothrombinase \\
\hline 0 & Control & 1.3 & 0.25 & 0.05 \\
\hline 1 & Thrombin inhibition & 10.0 & 0.25 & 0.05 \\
\hline 2 & $\mathrm{Xa}$ inhibition & 1.3 & 10.0 & 0.05 \\
\hline 3 & + Prothrombinase inhibition & 1.3 & 10.0 & 2.00 \\
\hline
\end{tabular}

respectively factor $\mathrm{V}$ and prothrombin is negligible, while nearly complete activation results for values of $\mathrm{Qx}_{\mathrm{a}}$ exceeding $5 \mathrm{pM}$ (factor Va) and $20 \mathrm{pM}$ (prothrombin). With respect to transient inputs of given duration, the system thus appears to be stable, in contrast to systems in which the response cannot be arbitrarily restrained by limiting the size of the input. It appears from figure 4 that such a restrained response results only for minute inputs. This raises the question whether the robustness of the system can be influenced by down-regulation, for instance by enhancing the inactivation rates of factor 

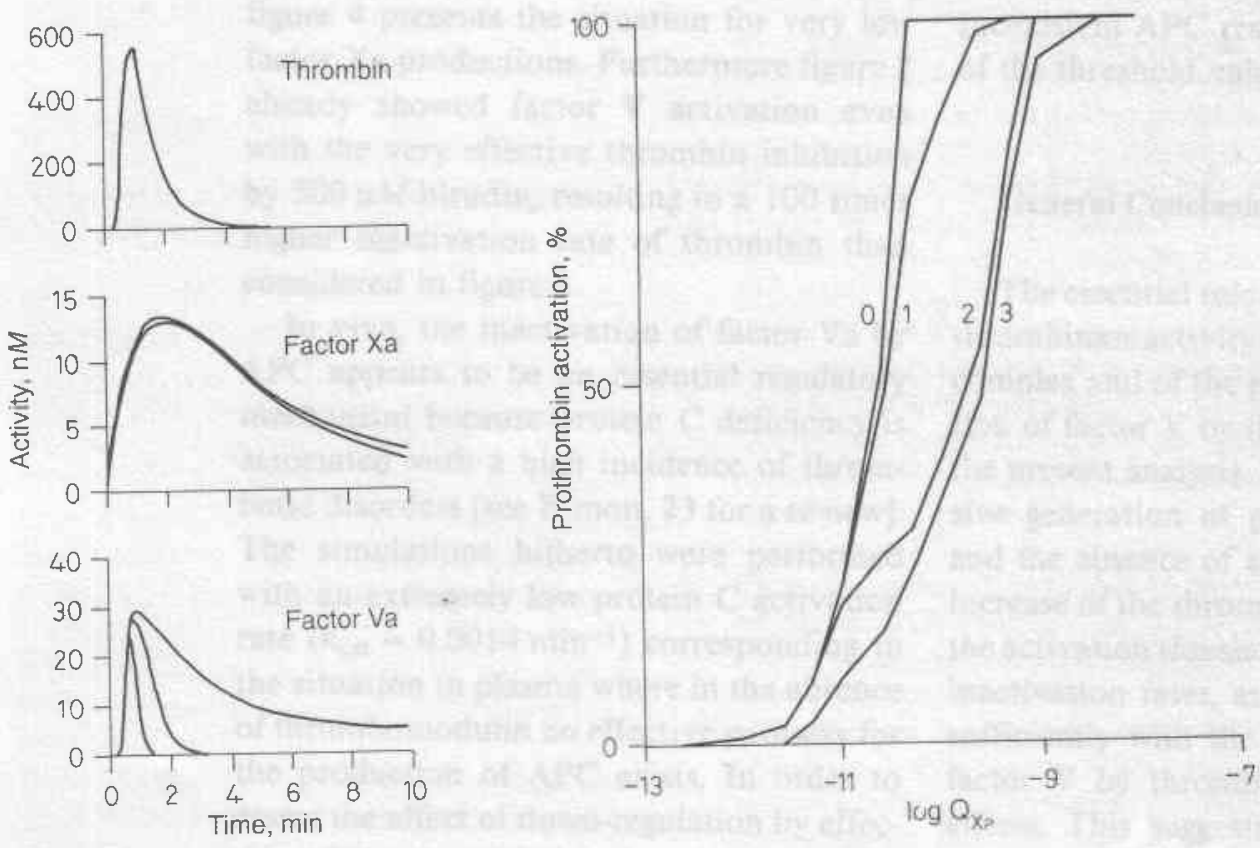

Fig. 5. The effect of the activation rate of protein C. Left panel shows the simulated plasma activities of thrombin, factor $\mathrm{Xa}$ and factor $\mathrm{Va}$ after a trigger of Xa production $\left(\mathrm{Q}_{\mathrm{Xa}}=20.0 \mathrm{n} M\right)$ for three activation rates $(0)$ 0.0014, (1) 0.0070 and (2) $0.035 \mathrm{~min}^{-1}$. Right panel shows the effect of the increased activation rate of protein $\mathrm{C}$ on the extent of prothrombin activation as a function of the factor Xa generation. Also shown is the inputresponse relation for $\mathbf{k}_{\mathrm{cat}}=0.035 \mathrm{~min}^{-1}$ for a steady-state base level of $1 \mathrm{nM} \mathrm{APC} \mathrm{(3).}$

$\mathrm{Xa}$ and/or thrombin. Therefore the inputresponse relation was also determined for the following conditions: (1) enhanced inactivation of thrombin with a rate constant of $10 \mathrm{~min}^{-1}$; (2) enhanced factor Xa inactivation with a rate constant of $10 \mathrm{~min}^{-1}$; (3) both enhanced factor $\mathrm{Xa}$ inactivation with a rate constant of $10 \mathrm{~min}^{-1}$ and enhanced prothrombinase inactivation with a rate constant of $2.0 \mathrm{~min}^{-1}$. These values of rate constants are chosen in the range of the observed inactivation rates in the presence of therapeutic concentrations of standard hepa- rin [3]. Figure 4 shows that increased thrombin inhibition does not affect the inputresponse relation for prothrombin activation and causes only a small shift of this relation for factor $V$ activation. In contrast, anti-factor $\mathrm{Xa}$ activity increases the robustness of the system enormously with an upward shift of the activation thereshold of 2 orders of magnitude. Additional inhibition of prothrombinase reinforces this effect. This is seemingly in contrast with the predominant role of thrombin in the generation of prothrombinase activity as discussed at fig- 
ures 2 and 3 , but it should be stressed that figure 4 presents the situation for very low factor Xa productions. Furthermore figure 2 already showed factor $\mathrm{V}$ activation even with the very effective thrombin inhibition by $500 \mathrm{n} M$ hirudin, resulting in a 100 times higher inactivation rate of thrombin than considered in figure 4.

In vivo, the inactivation of factor $\mathrm{Va}$ by APC appears to be an essential regulatory mechanism because protein $\mathrm{C}$ deficiency is associated with a high incidence of thrombotic disorders [see Esmon, 23 for a review]. The simulations hitherto were performed with an extremely low protein $\mathrm{C}$ activation rate $\left(k_{\text {cat }}=0.0014 \mathrm{~min}^{-1}\right)$ corresponding to the situation in plasma where in the absence of thrombomodulin no effective pathway for the production of APC exists. In order to assess the effect of down-regulation by effective APC generation, we determined the dependence of the input-response relation on the protein $\mathrm{C}$ activation rate by thrombin. The simulations in the left panel of figure 5 show that a 5- or 25-fold increase of the protein $\mathrm{C}$ activation rate has an enormous effect on the factor Va activity curves but leaves the thrombin generation curve unaffected. The right panel of this figure shows, however, that the input-response relation becomes more gradual for high protein $\mathrm{C}$ activation rates. Up to factor Xa productions of $10 \mathrm{p} M$, the responses practically coincide ( $<20 \%$ prothrombin activation), but for higher values of $\mathrm{Q}_{\mathrm{Xa}}$ the prothrombin activation lags behind for high protein $\mathrm{C}$ activation rates $\left(0.035 \mathrm{~min}^{-1}\right)$. This raises the question whether the system response for low values of $\mathrm{QX}_{\mathrm{Xa}}$ can be further limited by assuming that, in addition to this high activation rate, a small percentage of protein $\mathrm{C}$ is always present in the activated state. Fig- ure 5 indeed shows that an amount of $1 \%$ preexistent APC results in a moderate shift of the threshold value.

\section{General Conclusions}

The essential roles of the tremendous prothrombinase activity of the factor Va-Xa-lipid complex and of the positive feedback activation of factor $V$ by thrombin are stressed by the present analysis. This explains the explosive generation of prothrombinase activity and the absence of any effect of a moderate increase of the thrombin inactivation rate on the activation threshold. Only extremely high inactivation rates, as with hirudin, interfere sufficiently with the feedback activation of factor $\mathrm{V}$ by thrombin to cause significant effects. This suggests that reduction of the gain of this feedback loop, for instance by an immediate reduction of prothrombinase activity, as reported for ATIII + heparin in a purified system [17], could represent an effective mechanism to reduce the explosivity of the system. Furthermore this analysis indicates that the possible contribution of factor $\mathrm{Xa}$ to the activation of factor $\mathrm{V}$ is negligible unless the factor Xa concentration is very low or thrombin inactivation proceeds at unrealistic high rate constants, exceeding $200 \mathrm{~min}^{-1}$. The existence of an activation threshold for transient factor $\mathrm{Xa}$ generation is demonstrated and this stresses the relevance of effective degradation of the factor-Xa-generating capacity of tissue factor VIIa [24]. The good agreement between model predictions and measured activities in plasma suggests that the proposed model is essentially valid. However, the model parameters used were obtained from studies in purified systems and further identification of these parameters di- 
rectly from the plasma activation curves is a next step to consolidate the model.

\section{Acknowledgments}

We thank Dr. J Pieters for providing the data and Dr. S. Beguin for stimulating discussions.

\section{References}

1 Jackson CM, Nemerson Y: Blood coagulation. Ann Rev Biochem 1980;49:765-811.

2 Hemker HC; Willems GM, Beguin S: A computer assisted method to obtain the prothrombin activation velocity in whole plasma independent of thrombin decay processes. Thromb Haemost 1986;56:9-17.

3 Beguin S, Lindhout T, Hemker HC: The mode of action of heparin in plasma. Thromb Haemost 1988;60:457-462.

4 Pieters J, Lindhout T: The limited importance of factor Xa inhibition to the anticoagulant property of heparin in thromboplastin-activated plasma. Blood 1988;72:2048-2052.

5 Pieters J, Lindhout T, Hemker HC: In situ-generated thrombin is the only enzyme that effectively activates factor VIII and factor V in thromboplastin-activated plasma. Blood 1989;74:1021-1024.

6 Ofosu FA, Sie P, Modi GJ, Fernandez F, Buchanan MR, Blajchman MA, Boneus B, Hirsch J: The inhibition of thrombin-dependent positive-feedback reactions is critical to the expression of the anticoagulant effect of heparin. Biochem J 1987; 243:579-588.

7 Monkovic DB, Tracy PB: Activation of human factor $\mathrm{V}$ by factor $\mathrm{Xa}$ and thrombin. Biochemistry 1990;29:1118-1128.

8 Macfarlane RG: An enzyme cascade in the blood clotting mechanism, and its function is a biochemical amplifier. Nature 1964;202:498-499.

9 Levine SN: Enzyme amplifier kinetics. Science 1969;152:651-653.

10 Martorana F, Moro A: On the kinetics of enzyme amplifier systems with negative feedback. Math Biosci 1974;21:77-84.

11 Khanin MA, Semenov VV: A mathematical model of the kinetics of blood coagulation. J Theor Biol 1989;136:127-134.
12 Smith GF: Fibrinogen - The specific thrombin substrate; in Machovich R (ed): The Thrombin. Boca Raton, CRC Press, 1984, vol 1, pp 55-82.

13 Schoen $P$, Lindhout T: The in situ inhibition of prothrombinase formed human $\alpha$-thrombin and meizothrombin (des F1) by antithrombin and heparin. J Biol Chem 1987;262:11268-11274.

14 Forster WB, Nesheim ME, Mann KG: The factor Xa-catalyzed activation of factor V. J Biol Chem 1983;258:13970-13977.

15 Giesen PLA, Willems GM, Hermens WTh: Membrane mediated assembly of the prothrombinase complex. J Biol Chem, in press.

16 Solymoss S, Tucker MM, Tracy PB: Kinetics of inactivation of membrane-bound factor Va by activated protein C. J Biol Chem 1988;263:1488414890.

17 Schoen P, Lindhout T, Willems GM, Hemker HC: Antithrombin III-dependent anti-prothrombinase activity of heparin and heparin fragments. J Biol Chem 1989;264:10002-10007.

18 Rosing J, Tans G, Govers-Riemslag JWP, Zwaal RFA, Hemker HC: The role of phospholipids and factor $\mathrm{Va}$ in the prothrombinase complex. J Biol Chem 1980;255:274-283.

19 Hermens WTh, Kop JMM, Willems GM: Adsorption of coagulation factors II, $\mathrm{V}$, and $\mathrm{X}$ at phospholipid membranes; in Zwaal RFA, (ed): Coagulation and Lipids. Boca Raton, CRC Press, 1988, pp 73-97.

20 NAG library: Numerical algorithms group. Oxford, 1990.

21 Beguin S, Lindhout T, Hemker HC: The effect of trace amounts of tissue factor on thrombin generation in platelet rich plasma, its inhibition by heparin. Thromb Haemost 1989;61:25-29.

22 Stone SR, Hofsteenge J: Kinetics of the inhibition of thrombin by hirudin. Biochemistry 1986;25: 4622-4628.

23 Esmon CT: The regulation of natural anticoagulant pathways. Science 1987;235:1348-1352.

24 Rapaport SI: Inhibition of factor VIIa/tissue factor-induced blood coagulation: With particular emphasis upon a factor Xa-dependent inhibitory mechanism. Blood 1989;73:359-365.

\section{George M. Willems PhD}

Cardiovascular Research Institute Maastricht Biomedical Center, University of Limburg PO Box 616 NL-6200 MD Maastricht (The Netherlands) 